\title{
Investigation of the biotechnological properties of Zygosaccharomyces kombuchaensis and Gluconacetobacter xylinus as promising microorganisms for the production of functional drinks
}

\author{
Maria Babakina*, Tatyana Pershakova, and Maria Samoylenko \\ Krasnodar Research Institute of Agricultural Products Storage and Processing - branch of FSBSO \\ "North-Caucasian Federal Scientific Center of Horticulture \& Viniculture", 2 st. Topolinaya alleya, \\ Krasnodar, 350072, Russia
}

\begin{abstract}
The issues of biological conversion of products of processing plant raw materials remain invariably relevant. The development of processing secondary resources allows to increase the efficiency of food production, solving environmental problems and to contribute to ensuring food security. The paper presents data on the results of studies of biotechnological properties of yeast cultures Zygosaccharomyces kombuchaensis sp. and bacteria Gluconoacetobacter xylinus (Brown 1886) Yamada et al 1998, constituting a symbiotic culture called SCOBY (symbiotic culture of bacreties and yeasts), adapted and cultivated in the Krasnodar Territory with the aim of their further use for biological conversion of fruit and berry raw materials and secondary raw materials for the production of functional drinks. The optimal values for the cultivation of the studied cultures were established: $\mathrm{pH}-6.5$, temperature - for Zygosaccharomyces kombuchaensis $s p$. minimum growth temperature $\mathrm{t}=$ $+15-20{ }^{\circ} \mathrm{C}$, maximum $-\mathrm{t}=+45-50{ }^{\circ} \mathrm{C}$, for Gluconoacetobacter xylinus (Brown 1886) Yamada et al 1998 minimum growth temperature $\mathrm{t}=+10$ $25{ }^{\circ} \mathrm{C}$, maximum $-\mathrm{t}=+45-50{ }^{\circ} \mathrm{C}$; the content of reducing substances is 10-15\%. The data obtained will be used to develop biotechnological processes for the production of functional drinks.
\end{abstract}

\section{Introduction}

Currently, there is a growing interest in fermented functional foods [1]. The advantage of fermentation processes is that when they are carried out, the value of unused plant waste is increased; environmental safety is ensured, since the processes are natural and do not involve the use of hazardous pollutants; efficiency of processes.

\footnotetext{
* Corresponding author: wuhdz@mail.ru
} 
There are known researches on the technology of fermentation of sucrose, tea leaves, as well as other raw materials (cereals or plant leaves, fruit pomace, juices, coconut water) or animal products (milk, whey) [2-4].

This fermentation is carried out by a characteristic consortium of yeast and bacteria called SCOBY (symbiotic culture of bacteria and yeast) $[5,6]$. The microbiological composition of a consortium can vary depending on factors such as climate, geographic location, and the environment used for the fermentation process [7, 8].

Among the acetic bacteria that are part of the consortium, Gluconoacetobacter xylinus (Brown 1886) Yamada et al 1998 should be distinguished, since the cellulose that makes up SCOBY is synthesized by it [9-15].

As a result of fermentation of the yeast Zygosaccharomyces kombuchaensis sp. a complex containing sugars is formed; polyphenols; organic food acids; cellulose fibers; amino acids; macro- and microelements such as $\mathrm{Cu}, \mathrm{Fe}, \mathrm{Mn}, \mathrm{Ni}$ and $\mathrm{Zn}$; water-soluble vitamins such as vitamin C, B vitamins; carbon dioxide; antibiotic substances and hydrolytic enzymes.

In this regard, our interest was to study the biotechnological properties of yeast cultures Zygosaccharomyces kombuchaensis sp. and bacteria Gluconoacetobacter xylinus (Brown 1886) Yamada et al 1998, constituting a symbiotic culture called SCOBY (symbiotic culture of bacreties and yeasts), adapted and cultivated in the Krasnodar Territory with the aim of their further use for biological conversion of fruit and berry raw materials and secondary raw materials for the production of functional drinks.

\section{Materials and methods}

As objects of research, pure cultures of yeast and bacteria that make up a symbiotic culture of bacreties and yeasts (SCOBY), adapted and cultivated in the Krasnodar Territory, were selected.

Experimental studies were carried out using a set of indicators according to standard methods used in scientific practice.

The assessment of the resistance of microorganisms to high and low $\mathrm{pH}$ was carried out as follows: cultures preliminarily grown to the stationary growth phase were precipitated by centrifugation $\left(5000 \mathrm{rpm}, 10\right.$ minutes, $25^{\circ} \mathrm{C}$ ), then resuspended in a liquid nutrient medium with (final cell concentration $10^{8} \mathrm{CFU} / \mathrm{ml}$ ), the cells were re-precipitated by centrifugation $\left(5000 \mathrm{rpm}, 10\right.$ minutes, $25^{\circ} \mathrm{C}$ ) and resuspended in a liquid nutrient medium with $\mathrm{pH} 3.5,6.5$ and 9.5. The acidity of the medium was adjusted to the required molar concentration hydrochloric acid solution (with $\mathrm{HCl})=0.1 \mathrm{~mol} / \mathrm{L}$ and sodium hydroxide solution of molar concentration (with $\mathrm{NaOH}$ ) $=0.1 \mathrm{~mol} / \mathrm{L}$. The analysis of the growth of the studied microorganisms was carried out at a temperature of $+(27 \pm 1)^{\circ} \mathrm{C}$. Samples were taken from the moment the culture was set on medium, then after $6,12,24$ hours. To determine the number of cells in the medium, the method of seeding on solid nutrient media (Koch's method) was used.

To determine the temperature of optimal growth of the studied microorganisms, they were grown on Petri dishes on MPA medium for bacteria, and Sabouraud medium for yeasts. The analysis of the growth was held at temperature conditions: $+(10 \pm 1)^{\circ} \mathrm{C},+(15 \pm 1)^{\circ} \mathrm{C}$, $+(20 \pm 1){ }^{\circ} \mathrm{C},+(25 \pm 1){ }^{\circ} \mathrm{C},+(30 \pm 1){ }^{\circ} \mathrm{C},+(35 \pm 1){ }^{\circ} \mathrm{C}$ and $+(40 \pm 1){ }^{\circ} \mathrm{C},+(45 \pm 1){ }^{\circ} \mathrm{C},+(50 \pm 1){ }^{\circ} \mathrm{C}$, $+(55 \pm 1)^{\circ} \mathrm{C}$. The first control of growth was taken after 2 days, the second - after the next 3 4 days.

The assessment of the resistance of microorganisms to various concentrations of reducing substances was held by centrifugation and resuspension in a liquid nutrient medium with a concentration of reducing substances (glucose and fructose in a 1:1 ratio) of $10 \%, 20 \%, 30$ $\%$. 


\section{Results and discussion}

An assessment was made of the adaptive properties of the isolated and selected crops in media with different $\mathrm{pH}$.

In fig. 1 shows the growth activity of the studied cultures in a medium with a $\mathrm{pH}$ of 3.5.

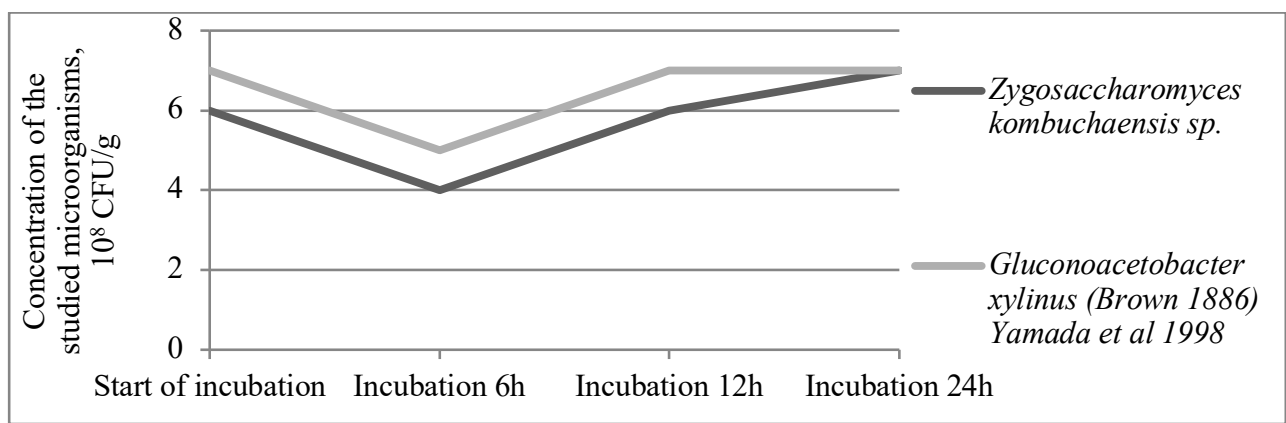

Fig.1. Growth activity of the studied microorganisms during incubation in a medium with $\mathrm{pH} 3.5$

In fig. 2, you can see the growth activity of the studied cultures on a medium with a $\mathrm{pH}$ of 9.5 .

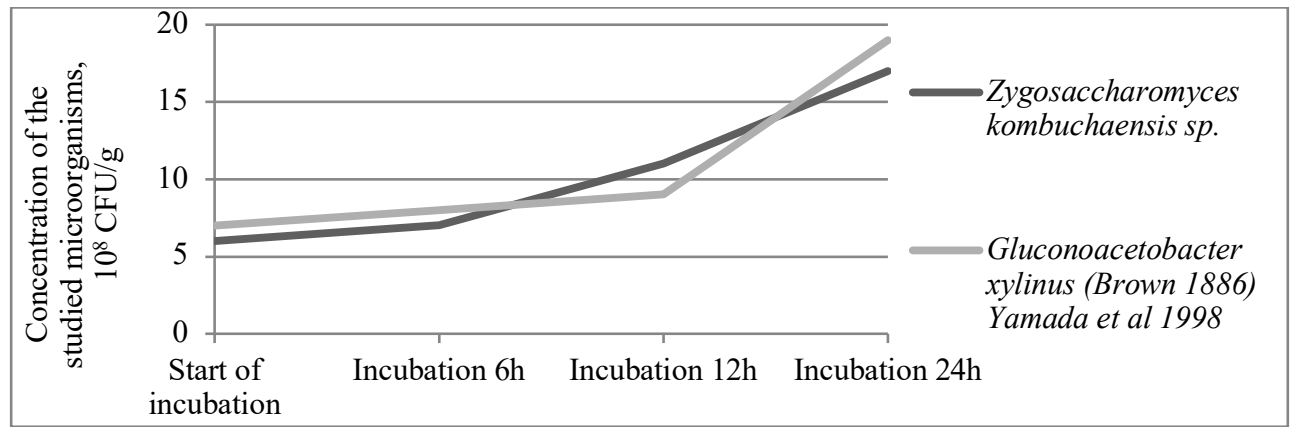

Fig. 2. Growth activity of the studied microorganisms during incubation in a medium with $\mathrm{pH} 9.5$

Figure 3 shows the growth activity of the studied cultures in a medium with a pH of 6.5 .

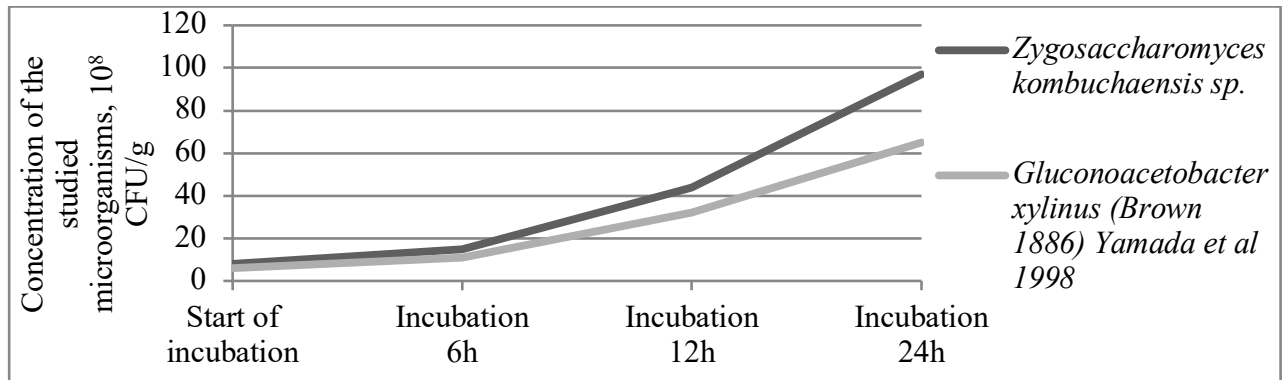

Fig. 3. Growth activity of the studied microorganisms during incubation in a medium with $\mathrm{pH} 6.5$

The next step was to determine the optimal growth temperatures for the studied microorganisms. The data on the effect of temperature on the growth of the studied microorganisms are presented in Table 1. 
Table 1. Influence of temperature on the growth of the studied microorganisms

\begin{tabular}{|l|l|l|l|l|l|l|l|l|l|l|l|}
\hline \multirow{2}{*}{ Studied microorganisms } & \multicolumn{10}{|c|}{ Cultivation temperature, ${ }^{\circ} \mathrm{C}$} \\
\cline { 2 - 23 } & 10 & 15 & 20 & 25 & 30 & 35 & 40 & 45 & 50 & 55 \\
\hline $\begin{array}{l}\text { Zygosaccharomyces kombuchaensis } \\
\text { sp. }\end{array}$ & - & - & $\mathrm{c}$ & + & + & + & \pm & $\mathrm{c}$ & - & - \\
\hline $\begin{array}{l}\text { Gluconoacetobacter xylinus (Brown } \\
\text { 1886) Yamada et al 1998 }\end{array}$ & - & $\mathrm{c}$ & \pm & + & + & + & \pm & $\mathrm{c}$ & - & - \\
\hline
\end{tabular}

Note: "+" - active growth; " $\pm "$ - less active growth; "c" - growth only after 5-6 days; "-" no growth at all.

It was also necessary to establish the effect of the increased content of reducing substances in order to reveal the growth rate and activity of the isolated and selected microorganisms. The results are shown in Table 2.

Table 2. Survival of the studied cultures with different content of reducing substances, CFU/g

\begin{tabular}{|l|c|l|l|l|l|}
\hline \multirow{2}{*}{$\begin{array}{c}\text { Studied } \\
\text { microorganisms }\end{array}$} & \multicolumn{2}{|l|}{$\begin{array}{l}\text { Concentration } \\
\text { of } \begin{array}{c}\text { reducing } \\
\text { substances, } \%\end{array}\end{array}$} & \multicolumn{4}{|l|}{ Incubation time, $\mathrm{h}$} & \multicolumn{1}{l|}{} \\
\cline { 3 - 6 } & 10 & $6 \times 10^{8}$ & $17 \times 10^{8}$ & $56 \times 10^{8}$ & $130 \times 10^{8}$ \\
\hline Zygosaccharomyces & 20 & $7 \times 10^{8}$ & $11 \times 10^{8}$ & $33 \times 10^{8}$ & $56 \times 10^{8}$ \\
kombuchaensis sp. & 30 & $5 \times 10^{8}$ & $6 \times 10^{8}$ & $10 \times 10^{8}$ & $13 \times 10^{8}$ \\
\hline $\begin{array}{l}\text { Gluconoacetobacter } \\
\text { xylinus (Brown 1886) }\end{array}$ & 10 & $5 \times 10^{8}$ & $10 \times 10^{8}$ & $38 \times 10^{8}$ & $77 \times 10^{8}$ \\
Yamada et al 1998 & 20 & $6 \times 10^{8}$ & $9 \times 10^{8}$ & $22 \times 10^{8}$ & $35 \times 10^{8}$ \\
\hline
\end{tabular}

Figure 1 shows that after 6 hours of incubation in medium with $\mathrm{pH} 3.5$, the number of viable cells for each culture decreased. After 12 and 24 hours, the number of viable cells in both cultures gradually increased and returned to the initial value, $7 \times 10^{8}$, but no increase in the number of cells occurred.

It can be argued that a medium with a $\mathrm{pH}$ of 3.5 stops and inhibits the growth of the studied microorganisms; therefore, further studies with a $\mathrm{pH}$ of 3.5 are inappropriate.

Based on Figure 2, it can be seen that after 24 hours of incubation, the number of Zygosaccharomyces kombuchaensis sp. cells increased 2.8 times from the initial one, and the number of Gluconoacetobacter xylinus (Brown 1886) Yamada et al 1998 cells increased 3.1 times. It can be argued that the medium with $\mathrm{pH} 9.5$ does not sufficiently stimulate the growth of both studied cultures.

Based on Figure 3, it can be seen that after 24 hours of incubation, the number of cells of Zygosaccharomyces kombuchaensis sp. increased 12 times from the initial, Gluconoacetobacter xylinus (Brown 1886) Yamada et al $1998-9.2$ times. It can be argued that the medium with $\mathrm{pH} 6.5$ actively stimulates the growth of both studied cultures, therefore, it is the most optimal of all the options selected.

Based on the data in Table 1, for Zygosaccharomyces kombuchaensis sp. minimum growth temperature $\mathrm{t}=+15-20^{\circ} \mathrm{C}$, maximum $-\mathrm{t}=+45-50{ }^{\circ} \mathrm{C}$. For Gluconoacetobacter xylinus (Brown 1886) Yamada et al 1998, the minimum growth temperature is $\mathrm{t}=+10-25^{\circ} \mathrm{C}$, the maximum is $\mathrm{t}=+45-50{ }^{\circ} \mathrm{C}$.

Table 2 shows that the amount of yeast Zygosaccharomyces kombuchaensis sp. for 24 hours of cultivation in a liquid nutrient medium with reducing substances at a concentration of $10 \%$ increased from the initial by $2066 \%$, in a medium with reducing substances at a concentration of $20 \%$ - by $700 \%$, in a medium with reducing substances at a concentration of $30 \%$ - by $160 \%$. The number of bacteria Gluconoacetobacter xylinus (Brown 1886) Yamada et al 1998 for 24 hours of cultivation in a liquid nutrient medium with reducing 
substances at a concentration of $10 \%$ increased from the initial by $1440 \%$, in a medium with reducing substances at a concentration of $20 \%$ - by $483 \%$, in a medium with reducing substances in a concentration of $30 \%$ - by $83 \%$.

Based on the data obtained, it can be argued that the optimal content of reducing substances in the medium for the growth of Zygosaccharomyces kombuchaensis sp. and Gluconoacetobacter xylinus (Brown 1886) Yamada et al 1998 is $10 \%$ and should not exceed $15 \%$, since a further increase in the content of reducing sugars inhibits the development of both microorganisms.

\section{Conclusion}

To summarize, in the present study, pure cultures of Zygosaccharomyces kombuchaensis sp. and Gluconoacetobacter xylinus (Brown 1886) Yamada et al 1998, members of the symbiotic consortia, were studied under various conditions. It was found that the medium with $\mathrm{pH} 6.5$ actively stimulates the growth of both studied cultures, it is the most optimal of all the options selected. The optimum concentration of reducing substances in the medium is $10-15 \%$. It was also revealed that both studied microorganisms actively grow at temperatures from $+(25 \pm 1)^{\circ} \mathrm{C}$ to $+(35 \pm 1){ }^{\circ} \mathrm{C}$.

\section{References}

1. S. Ebner, L.N. Smug, W. Kneifel, S.J. Salminen, M.E. Sanders. World J. Gastroenterol., 20(43), 16095-16100 (2014) https://doi.org/10.3748/wjg.v20.i43.16095

2. C.I. Gamboa-Gomez, L.E. Simental-Mendia, R.F. Gonzalez-Laredo, E.J. AlcantarOrozco, V.H. Monserrat-Juarez, J.C. Ramirez-España, J.A. Gallegos-Infante, M.R. Moreno-Jiménez, N.E. Rocha-Guzmán, Food Res. Int., 102, 690-699 (2017) https://doi.org/10.1016/j.foodres.2017.09.040

3. R.O. Lobo, B.K.C. Sagar, C.K. Shenoy, J. Microsop. Ultrastruct., 5, 146-154 (2017) https://doi.org/10.1016/j.jmau.2016.09.001

4. A. Sknepnek, M. Pantic, D. Matijasevic, D. Miletic, S. Levic, V. Nedovic et al., Int. J. Med. Mushrooms, 20, 243-258 https://doi.org/10.1615/IntJMedMushrooms.2018025833

5. S.A. Villarreal-Soto, S. Beaufort, J. Bouajila, J.P. Souchard, P. Taillandier, J. Food Sci., 83, 580-588, (2018) https://doi.org/10.1111/1750-3841.14068

$\begin{array}{lllllll}\text { 6. J.M. Kapp, W. Summer, Ann. Epidem., 30, 66-70 (2018) } & \end{array}$ https://doi.org/10.1016/j.annepidem.2018.11.001

7. S. Chakravorty, S. Bhattacharya, A. Chatzinotas, W. Chakraborty, D. Bhattacharya, R, Gachhui, Int. J. Food. Microbiol., 220, 63-72 (2016) https://doi.org/10.1016/j.ijfoodmicro.2015.12.015

8. M. Coton, A. Pawtowski, B. Taminiau, G. Burgaud, F. Deniel, L. Coulloumme-Labarthe, A. Fall, G. Daube, E. Coton, FEMS Microbiol. Ecol., 93(5), fix048 (2017) https://doi.org/10.1093/femsec/fix048

9. W.N. Goh, A. Rosma, B. Kaur, A. Fazilah, A.A. Karim, R. Bhat, Int. Food. Res. J., 19, 109-117 (2012) http://www.ifrj.upm.edu.my/19\%20(01)\%202011/(15)IFRJ-2011105\%20Rajeev.pdf

10. N. Goh, A. Rosma, B. Kaur, A. Fazilah, A.A. Karim, R. Bhat, Int. Food. Res. J., 19, 153$158 \quad$ (2012) http://www.ifrj.upm.edu.my/19\%20(01)\%202011/(20)IFRJ-2011106\%20Rajeev.pdf

11. A.-K. Waleed, K. Taous, U.-I. Mazhar, W. Fa, J. Polym. Environ., 23, 45-53 (2015) https://doi.org/10.1007/s10924-014-0663-X 
12. L. Wang, Z. Li, J. Hua, S. Jia, J. Zhang, H. Liu, Carbohydr. Polym., 120, 115-119 (2015) https://doi.org/10.1016/j.carbpol.2014.11.061

13. M.I. Watawana, N. Jayawardena, V.Y. Waisundara, J. Food Process. Preserv., 39(6), 2596-2603 (2015) https://doi.org/10.1111/jfpp.12509

14. J.A. Viesser, G.V. de M. Pereira, D.P. Carvalho Neto, H. Rogez, A. Góes-Neto, V. Azevedo, B. Brenig, F. Aburjaile, C.R. Soccol, Int. J. Food. Microbiol., 339, 109015 (2021) https://doi.org/10.1016/j.ijfoodmicro.2020.109015

15. M. Leal, V. Suárez, R. Jayabalan, H. Oros, A. Escarlante-aburto, J. Food, 16(1), 390-399 (2018) https://doi.org/10.1080/19476337.2017.1410499

\section{Acknowledgements}

The innovation project was carried out with the financial support of the Kuban Science Foundation in the framework of the Commercializable scientific andinnovation projects competition № NIP-20.1-59/20. 